\title{
Peran Orang tua Mengatasi Dampak Negatif Gadget pada Remaja Kristen
}

\author{
Lamris Sihotang ${ }^{1}$, Rulland Gerrit ${ }^{2}$, Ester Kartika ${ }^{3}$, Martina Novalina ${ }^{4}$ \\ 1,2,3,4Sekolah Tinggi Teologi Ekumene Jakarta \\ Correspondence email:
}

\begin{abstract}
The purpose of this study was: to determine the role of parents in overcoming the negative impact of gadgets that affect the character of teenagers. Parents must know that they have an important role in efforts to overcome the negative impact of using gadgets on teenagers. Researchers have explained the efforts made by parents to overcome the negative impact of gadgets on teenagers. The method in this research is qualitative by looking at cases in the field (case studies), data collection methods based on surveys or observations, and looking at previous studies that have been in journal form. The results of this study indicate that the role of parents in adolescents that must be carried out and carried out are: First, parents know and understand the rating of the game used by their child, the rating referred to here is the type of game played by the child, secondly, avoid installing electronic devices inside the children's room, the third creates rules that are agreed with the child, by treating time restrictions in using gadgets, the fourth parent actively monitors and pays attention to the media that is being consumed by the child, such as games and movies, the fifth communicates and discusses with the children what they it can be from the games or shows they watch, the six parents control the play store on the gadget, by selectively choosing game features that do not cause negative things to the child's character. Another thing that must be done by Christian families is to teach God's word continuously to children and guide children to always build fellowship with God. Parents become educators, as educators in the family provide time and place and give responsibility by entrusting tasks within the family. family, teach discipline and educate with the example of parents.
\end{abstract}

Keywords: adolescent character; Christian youth; gadget; parent's role

Abstrak: Tujuan dari penelitian ini adalah: untuk mengetahui peran Orang Tua dalam mengatasi dampak negatif gadget yang mempengaruhi Karakter anakanak Remaja. Orang tua harus mengetahui bahwa mereka memiliki peran penting sebagai upaya untuk mengatasi dampak negative penggunaan gadget pada anak remaja. Peneliti sudah men-jelaskan upaya yang dilakukan oleh orangtua untuk mengatasi dampak negatif gadget pada remaja. Metode penelitian yang dilakukan adalah Kualitatif, sedangkan metode pengam-bilan data berdasarkan survei atau observasi, serta melihat penelitian-penelitian sebe-lumnya yang sudah dalam bentuk jurnal. Hasil penelitian ini menunjukkan bahwa peran orang tua pada anak remaja yang harus dilakukan dan dikerjakan yaitu: Pertama, orang tua mengetahui dan memahami rating game yang digunakan oleh anaknya, rating yang dimaksud disini adalah jenis game yang dimainkan anak, kedua hindari pemasangan perangkat elektronik di dalam ruangan kamar anak, ketiga menciptakan aturan yang disetujui dengan anak, dengan cara memperlakukan pembatasan waktu dalam menggu-nakan gadget, keempat orangtua aktif mengawasi dan memperhatikan media yang sedang dikonsumsi oleh anak, seperti game dan film, kelima 
mengkomunikasikan dan mendis-kusikan pada anak mengenai apa saja yang mereka dapat dari game atau acara yang mereka tonton, keenam orang tua mengontrol play store yang di gadget, dengan cara selek-tif memilih fitur games yang tidak menimbulkan hal-hal negatif pada karakter anak. Hal la-in yang harus dilakukan oleh keluarga Kristen adalah mengajarkan firman Tuhan terus-menerus kepada anak dan membimbing anak senantiasa membangun persekutuan dengan Tuhan, orang tua menjadi pendidik, sebagai pendidik dalam keluarga menyediakan waktu dan tempat serta memberikan tanggung jawab dengan mempercayakan tugas-tugas di dalam keluarga, mengajarkan disiplin serta mendidik dengan keteladanan orang tua.

Kata kunci: gadget; karakter remaja; peran orangtua; remaja Kristen

\section{PENDAHULUAN}

Keluarga merupakan lembaga yang paling pertama dan utama dalam menanamkan pendidikan karakter pada anak sehingga dimasa yang akan datang anak mampu bermasyarakat dengan baik. Namun yang menjadi tantangan baru dalam menanamkan pendidikan karakter adanya perkembangan media teknologi yang semakin pesat dan tidak dapat terhindarkan. Sekarang ini anak usia dini hingga usia remaja sudah diberikan kebebasan dan kekuasaan dalam menggunakan gadget oleh orangtuanya. Para orang tua seringkali membuat alasan, bahwa dengan anak menggunakan gadget anak-anak lebih mudah dalam pengawasan dan lebih aman dibandingkan dengan anak beraktivitas di luar rumah. Namun dampak-dampak dari penggunaan gadget acapkali tidak dipikirkan oleh para orangtua.

Pesatnya perubahan teknologi dewasa ini tentu akan dapat mempengaruhi pola kehidupan manusia dalam berbagai bidang. Salah satu teknologi yang mempengaruhi pola perilaku dan karakter manusia adalah gadget. Hampir semua kalangan usia dan lapisan masyarakat dipastikan memiliki gadget dan aktif menggunakannya setiap hari. Hampir setiap hari gadget banyak digunakan oleh setiap orang untuk kegiatan-kegiatan penting sampai sekedar menghabiskan waktu untuk mengisi kekosongan atau sekedar mengisi waktu luang dalam setiap harinya. Tentu hal-hal tersebut sangat berdampak bagi para penggunaannya khususnya pada usia remaja.

Bagi seorang remaja, kemajuan teknologi ini menjadi sebuah tantangan tersendiri bagi mereka yaitu bagaimana menghadapi dan cara mengolahnya. Gadget adalah salah satu teknologi yang berkembang yang dimanfaatkan di kalangan masyarakat terutama dikalangan remaja masa ini. Gadget adalah salah satu sarana yang banyak digunakan oleh para remaja untuk mendapatkan informasi, untuk berkomunikasi, mempermudah dalam belajar, menjadi sarana menghasilkan uang, dan sebagainya. Dibalik dari pemanfaatan hal-hal positif dari gadget pada akhirnya akan membawa degradasi karakter bagi para remaja, jika salah dalam penggunaannya, seperti pengaruh pada kesehatan fisik, kesehatan mental, 
berdampak pada kemalasan, sulit fokus, kecanduan atau keterikatan pada gadget, membuat pribadi menjadi individual, kerusakan pada mata, dan sebagainya. Penggunaan gadget juga dapat berdampak bagi kehidupan karakter dan kerohanian para remaja, seperti menonton video yang tidak baik akibat menonton itu dapat melakukan dosa sehingga merugikan dirinya sendiri bahkan merugikan orang lain.

Permasalahan yang sering terjadi di masyarakat tentang penggunaan gadget banyak sekali, dapat kita lihat berdasarkan masalah yang ada di masyarakat, dalam artikel detikhealth melakukan penelitian survei jam penggunaan gadget kepada orang tua dan anak banyak orang tua protes ketika mengetahui anaknya lebih asyik dengan gadget ketimbang berinteraksi dengan keluarga atau teman-temannya. Sebuah survei yang disponsori Common Sense Media menyebut, orang tua rata-rata menghabiskan waktu dengan gadget selama 9 jam per hari. Namun ini bukan untuk kepentingan pekerjaan. Ada 80 persen responden dilaporkan bermain video games, media sosial, membuka-buka situs internet hingga menonton televisi di ponsel atau tablet mereka. Tahun lalu, survei yang sama juga dilakukan pada responden berusia 8-18 tahun. Hasilnya sama, remaja rata-rata menghabiskan waktu selama 9 jam dengan gadget mereka dalam sehari, sedangkan anak-anak (rentang usia 8-12 tahun) menghabiskan waktu enam jam dalam sehari bermain gadget. Orang tua dari umur 8-18 tahun yang ambil bagian dalam survei 78\% dari 1.800-an merasa sudah menjadi model, namun kenyataanya orang tua belum bisa melepaskan diri dari gadget, meskipun mereka mencemaskan anak-anak mereka, di sisi lain orang tua tidak menjadi contoh buat anak-anak mereka ${ }^{1}$.

Disinilah tantangan besarnya bagi semua orang tua, bagaimana peran orang tua dalam upaya mengatasi dan mengarahkan supaya anak-anak mereka menggunakan dan memanfaatkan kemajuan teknologi ini dengan baik dan benar. Atau justru kemajuan teknologi ini membawa pengaruh buruk bagi remaja itu sendiri, dimana yang justru orang tua tidak menjadi contoh yang baik untuk para remaja dalam mempergunakan gadget seperti permasalahan yang diteliti oleh artikel detikhealth. Berdasarkan uraian diatas peneliti akan meneliti mengenai peran orang tua mengatasi dampak negatif gadget pada remaja Kristen.

\section{METODE PENELITIAN}

Metode dalam penelitian ini menggunakan pendekatan kualitatif. Pengambilan data dilakukan melalui survei atau observasi, serta melihat penelitian-penelitian sebelumnya yang sudah dalam bentuk jurnal atau artikel-artikel, tentang temuan lapangan yang mereka dapatkan tentang Gadget.

\section{PEMBAHASAN}

Dalam pembahasan ini peneliti akan menjelaskan terlebih dahulu apa itu Gadget dan apa itu karakter remaja Kristen. Eka Anggraini dalam bukunya menuliskan, secara umum, gadget adalah sebuah perangkat atau alat elektronik yang berukuran identik kecil juga memiliki kegunaan khusus serta praktis di dalam peng-

${ }^{1}$ Rahma Lillahi Satira, "Survai: Orang Tua Dan Anak Habiskan Waktu Sama Banyaknya Bermain Gadget," DetikHealth. 
gunaanya. ${ }^{2}$ Dan, menurut Derry Iswidharmanjaya, Beranda Agency, gadget adalah merupakan perangkat atau instrumen elektronik yang memiliki tujuan memudahkan manusia dalam mencari dan mendapatkan informasi dengan cara yang praktis. ${ }^{3}$ Menurut Sylvie Puspita menuliskan dalam bukunya fenomena kecanduan gadget pada anak usia dini gadget adalah salah sebagai tanda majunya pertumbuhan dan kemajuan zaman di bidang teknologi. Dengan hadirnya gadget tidak dapat disangkal keberadaan gadget yang merupakan salah satu wujud kemajuan dalam bidang teknologi, berdasarkan data dari DetikNet tahun 2014 dari 47 juta penduduk Indonesia pengguna aktif, data menunjukkan $79,9 \%$ pengguna yang paling banyak adalah anak-anak dan remaja hanya untuk media social seperti hiburan. ${ }^{4}$ Efendi dalam bukunya menjelaskan gadget adalah sebuah istilah dalam bahasa Inggris yang mendefinisikan salah satu alat elektronik yang berukuran kecil yang dilengkapi berbagai macam kegunaan khusus. Dalam bahasa Indonesia, gadget disebut sebagai "gawai". Istilah gadget sebagai benda dengan karakteristik unik, memiliki sebuah unit dengan kinerja yang tinggi dan berhubungan dengan ukuran serta biaya. ${ }^{5}$

Sedangkan terbentuknya karakter merupakan pengembangan dari unsurunsur harkat dan martabat manusia secara keseluruhan bersesuaian dengan nilainilai yang terkandung dalam kehidupan manusia yang lebih baik. Muchlas Saman mengatakan salah satu yang menentukan karakter remaja ditinjau dari perkembangan umur adalah remaja dini (13-14) bahwa remaja awal pada laki-laki dan perempuan yang mempengaruhi pertumbuhan karakternya adalah lingkungan keluarga yang lebih dominan mempengaruhi sikap moral anak untuk membentuk karakternya; remaja madya (15-17) bahwa pada usia ini remaja madya pada anak laki-laki dan perempuan yang mempengaruhi sifat pembentukan karakternya adalah naluri, yang ada pada diri remaja itu sendiri; remaja lanjut (18-21) pada usia ini remaja lanjut pada anak laki-laki dan perempuan bahwa sifat yang lebih mendominasi mempengaruhi karakternya adalah tabiat, watak dalam diri remaja lanjut.

Pada umumnya ada beberapa faktor yang mempengaruhi proses pembentukan karakter seperti: hakikat manusia, yang meliputi unsur: makhluk yang beriman dan bertaqwa paling sempurna, paling tinggi derajatnya, khalifah di muka bumi; dimensi kemanusiaan meliputi: dimensi kefitrahan, kebenaran dan keluhuran. Dimensi ke individual, potensi dan perbedaan. Dimensi keberagamaan, iman dan taqwa. Penampilan lima unsur dimensi kemanusiaan dalam kehidupan seharihari akan mencerminkan karakter manusia.

Tong (2009:26) berkata pembentukan karakter remaja Kristen merupakan hal yang sangat penting, hal yang prinsip yang penting di dalam pembentukan karakter seorang murid, yaitu kasih dan keadilan yang dilakukan secara benar, seimbang

\footnotetext{
2 Eka Anggraini, Mengatasi Kecanduan Gadget Pada Anak (Serayu Publishing, 2019).

3 Derry Iswidharmanjaya, Bila Si Kecil Bermain Gadget (Desember 2014, 2014).

${ }^{4}$ Ratna Pangastuti, "Fenomena Kecanduan Gadget Pada Usia Dini," Indonesia Jurnal Of Islamic Early Childhood Educatiuon Vol.2, No. (2017): 166.

5 Puji Asmaul Chusna, "Pengaruh Media Gadget Pada Perkembangan Karakter Anak," Dinamika Penelitian: Media Komunikasi Sosial Keagamaan 17, no. 2 (2017): 315-330.
} 
akan menghasilkan bijaksana. Adapun hasil dari keseimbangan ini tentu akan mendatangkan kuasa yang luar biasa. Bijaksana adalah satu rahasia untuk memberikan keseimbangan ini akan memberikan pengaruh yang luar biasa. Bijaksana adalah satu rahasia untuk memberikan keseimbangan antara cinta kasih dan keadilan, dan hasil dari kesinambungan ini akan memberikan pengaruh yang luar biasa bagi hidup ${ }^{6}$. Adapun karakter remaja Kristen harus bertumbuh dalam segala hal ke arah kristus. Dan pertumbuhan tersebut mencakup perubahan pola pikir, yang mengarah pada perubahan perilaku dan karakter Kristus. Wikipedia menggambarkan karakter sebagai sifat manusia pada umumnya, seperti pemarah, sabar, pemaaf dan sebagainya. Maka Karakter Kristus adalah sifat yang seharusnya ada pada seorang Kristen sebagai pengikut Kristus. Adapun sifat yang seharusnya ada pada diri Kristen adalah Efesus 4:15 mengarahkan umat bertumbuh dalam segala hal (termasuk karakter) ke arah Kristus. Dengan demikian, maka remaja Kristen perlu mewarisi dan menyatakan sifat-sifat Kristus dalam hidup. ${ }^{7}$

Data APJII (Asosiasi Penyelenggara Jasa Internet Indonesia) menunjukkan bahwa penggunaan internet di Indonesia sudah mencapai $64,8 \%$ dari jumlah penduduk Indonesia. Dari pengguna internet sebanyak itu ternyata pengaksesnya didominasi oleh generasi milenial (20-34 tahun) dan generasi Z (10-19 tahun). Adapun kecenderungan pengguna gadget di Indonesia kurang produktif. Mereka lebih cenderung menggunakan gadget untuk media sosial, ketimbang aplikasi yang bermanfaat. Pada hal muatan media sosial tidak selamanya baik dan bermanfaat. Tak jarang pornografi dan kekerasan ditemui tersebar dengan bebas di dunia maya dan terhubung dengan dengan anak-anak dan remaja melalui gadget.

Selain kontennya bisa berdampak negatif, namun penggunaan gadget secara intens juga dapat menimbulkan kecanduan bagi penggunanya. Khususnya bila digunakan secara terus-menerus. Pada bulan Oktober 2019 Rumah sakit jiwa (RSJ) Provinsi Jawa barat merilis berita yang mengejutkan, di mana ratusan anak mengalami gangguan jiwa akibat kecanduan gadget tengah dirawat. Adapun hasil pemeriksaan tim medis menyatakan masalah yang dialami anak-anak tersebut disebab-kan oleh penggunaan gadget yang berlebihan, yaitu mulai dari game online, browsing internet dan aplikasi lainnya. ${ }^{8}$ Adapun dampak-dampak dari penggunaan gadget secara intens tentu akan sangat berpengaruh pada karakter-karakter negatif pada usia remaja termasuk remaja Kristen. Berikut yang merupakan dampak buruk atau dampak negatif penggunaan gadget pada remaja: Pertama, menjadi pribadi tertutup, ketika anak telah kecanduan gadget mereka akan memiliki pemahaman gadget itu adalah bagian dari hidupnya. Mereka akan merasa cemas saat gadget dijauhkan dari mereka. Waktu mereka akan tersita untuk bermain dengan gadget. Hal ini tentu akan mengganggu kedekatan dengan orangtua, lingkungan bahkan

${ }^{6}$ Andrianus Nababan, "Pola Asuh Demokratis Orangtua Kristen Dalam Pembentukan Karakter Remaja," Jurnal Dinamika Pendidikan 13, no. 2 (2020): 127-134.

7 Ronald Sirait, Digital Karakter Presfektif Agama Dan Pendidikan, Yayuk Umay. (CV. Multimedia Edukasi, 2020).

${ }^{8}$ Azimah Subagijo, Diet Dan Detoxs Gadget (PT Mizan Publika, 2020). 
teman sebayanya. Jika dibiarkan keadaan ini akan membuat anak menjadi pribadi tertutup atau introvert.

Kedua, suka menyendiri, ketika anak sudah merasa asik dengan gadget-nya tentu ia tidak peduli dengan apapun yang terjadi disekitarnya karena yang dibutuhkan adalah bermain dengan gadget itu pun dilakukan sendiri tanpa siapapun. Saat ia berada di sekolah dia akan mengalami kesulitan berinteraksi atau berkomunikasi secara sehat. Dalam kehidupan yang nyata ia akan mengalami kesulitan untuk fokus sehingga ia menjadi seorang pribadi yang menyendiri. Ketiga perilaku kekerasan, perilaku kekerasan yang acap kali terjadi pada anak disebabkan karena anak intens menyaksikan atau mengonsumsi materi kekerasan baik itu melalui game atau media sosial (youtube, facebook) yang menampilkan kekerasan. Keempat pudarnya kreativitas, tersedianya gadget, kecenderungan anak menjadi pasif, malas dan menjadi kurang kreatif. Hal ini disebabkan saat ia diberi tugas oleh sekolah ia tidak akan membaca buku tetapi langsung browsing internet untuk menyelesaikan tugas yang diberikan oleh sekolah. Gadget sangat membantu dan memudahkan seorang remaja dalam belajar tetapi disisi lain kreativitasnya tentu akan terancam memudar apabila ia menggantungkan perangkat tersebut.

Harus dipahami usia anak-anak akan lebih baik jika menggunakan kreativitas untuk proses pembelajaran karen sangat berpengaruh pada perkembangan pada usia selanjutnya. ${ }^{9}$ Untuk remaja Kristen sendiri dampak gadget akan mempengaruhi karakter mereka yang berhubungan dengan kehidupan kerohanian kepada Tuhan, karena gadget dapat mengakibatkan kecanduan sehingga lebih mengutamakan gadget melalaikan tanggung jawab yang seharusnya seperti tugas, aktifitas lainya, terlebih lagi kehidupan rohaninya. Kedua gadget dapat menjadi berhala karena sudah kecanduan tidak bisa menguasai pemakaiannya apalagi jika lewat tontonan bisa melakukan dosa, ketiga gadget dapat menghambat pertumbuhan rohani dalam hal doa, membaca Alkitab, serta tidak fokus dalam beribadah karena disibukkan memainkan gadget. Dari data yang peneliti lakukan secara langsung lewat wawancara kepada remaja Kristen, rata-rata waktu yg mereka gunakan untuk menggunakan gadget adalah 4-6 Jam dalam sehari, dan lebih banyak menggunakan gadget untuk chatting, hiburan lewat media sosial seperti IG, FB, Games, dan Youtube.

Setelah membahas dampak-dampak negatif dari penggunaan gadget pada karakter remaja Kristen, maka diperlukan peran serta dari orang tua bagaimana mengatasi atau mengantisipasi agar remaja Kristen terhindar dari pengaruhpengaruh buruk dari penggunaan gadget. Orang tua merupakan sosok yang paling utama dan yang paling berpengaruh dalam mengatasi dan mencegah dampak negatif dari penggunaan gadget. Mereka sangat berperan dalam mengarahkan, membina agar penggunaan gadget tidak berdampak negatif bagi anak remaja. Beberapa cara-cara pencegahan atau mengatasi dampak gadget pada anak remaja yaitu: 1) Sebaiknya orang tua mengetahui dan memahami rating game yang digunakan oleh anaknya, rating yang dimaksud disini adalah jenis game yang

${ }_{9}^{9}$ Anggraini, Mengatasi Kecanduan Gadget Pada Anak. 
dimainkan anak; 2) Hindari pemasangan perangkat elektronik di dalam ruangan kamar anak; 3) Menciptakan aturan yang disetujui dengan anak, dengan cara memperlakukan pembatasan waktu dalam menggunakan gadget; 4) Orangtua aktif mengawasi dan memperhatikan media yang sedang dikonsumsi oleh anak, seperti game dan film; 5) Mengomunikasikan dan mendiskusikan pada anak mengenai apa saja yang mereka dapat dari game atau acara yang mereka tonton; 6) Orang Tua mengontrol play store yang di gadget, dengan cara selektif memilih fitur games yang tidak menimbulkan hal-hal negatif pada karakter anak remaja. ${ }^{10}$

Intan Permata Sari, Rama W. Kusuma, \& Ahmad Syaiful Amal dalam jurnalnya yang berjudul "Peran orangtua mencegah dampak negatif gadget melalui pendekatan komunikasi dan psikologi" menemukan bahwa peran pola komunikasi orangtua adalah cara yang sangat penting dalam mengatasi ketergantungan remaja pada gadget, dan juga bagaimana pola komunikasi yang tepat kepada anak akan berpengaruh besar dalam pembentukan karakter anak itu sendiri. Dengan kata lain, jika orangtua tidak tepat dalam menerapkan pola komunikasi akan berdampak negatif kepada pembentukan karakter anak tersebut. Namun sebaliknya, jika pola komunikasi yang diterapkan orangtua terhadap anak sudah tepat maka akan berdampak baik dalam pembentukan karakter anak tersebut. Lebih lanjut lagi, dikatakan disitu bahwa pola komunikasi yang ada dalam keluarga sangat menentukan bagaimana orangtua dapat tetap menjaga anaknya terhindar dari dampak negatif penggunaan gadget.

Dari pola komunikasi ini orangtua dapat terus memberikan pengertian, mengawasi, bahkan tetap memegang kendali kondisi psikologi anak. Kedekatan hubungan orang tua dengan anak memiliki peran penting untuk bagaimana orang tua menerapkan pola komunikasi yang ada baik secara interpersonal, verbal, maupun nonverbal. Ketika semua hal ini dilakukan oleh orangtua maka anak remaja akan tetap dalam kendali orangtua. Bahkan, orang tua dapat menyeleksi apa-apa saja yang anak remajanya dapat lakukan dalam gadget tersebut, termasuk apa saja yang mereka dapat akses dan permainan apa saja yang mereka dapat dimainkan tanpa adanya penolakan dari anak tersebut. Hal ini terjadi karena orangtua memiliki kedekatan hubungan yang baik sehingga pola komunikasi dapat berjalan dengan baik pula. Kedekatan hubungan ini harus dibangun bahkan harus dibangun anak masih dalam kandungan, saat itu juga pola komunikasi perlahan mulai dibangun. Tanpa adanya kedekatan hubungan orangtua dengan anak maka apapun itu akan sangat tidak mudah untuk mengatasi permasalahan-permasalahan anak remaja yang ada. Menyadari pentingnya peran orangtua dalam setiap masa pertumbuhan dan perkembangan anak serta bagaimana orangtua dapat menerima dan mengolah setiap kelebihan serta kelemahan anak menjadi kunci dari bagaimana anak remaja

${ }^{10}$ Intan Permata Sari, Rama W Kusuma Wardhani, and Ahmad Syaiful Amal, "Peran Orang Tua Mencegah Dampak Negatif Gadget Melalui Pendekatakan Komunikasi Dan Psikologi * Corresponding Author Pendahuluan Gadget Diartikan Sebagai Suatu Alat Yang Digunakan Untuk Mengakses Atau Menjalankan Suatu Program Tertentu Yang Menarik Dan Ber” 2, no. 2 (2020): 267-289. 
dapat terhindar dari dampak negatif gadget sehingga anak remaja tetap dalam perkembangan karakter yang baik dan benar ${ }^{11}$.

Sebagai orang tua dari remaja Kristen, sangat penting untuk memiliki sikap yang kritis dalam menerima perkembangan era digital. Orang tua bertugas menanamkan prinsip-prinsip dalam Alkitab sebagai acuan kuat bagi keluarga Kristen dalam mengajarkan pendidikan agama Kristen kepada anak remaja agar tidak terpengaruh oleh hal-hal yang ditimbulkan oleh penggunaan gadget. Beberapa tindakan yang dilakukan oleh keluarga Kristen yaitu: 1) Mengajar dengan membicarakannya Ulangan 11:19 "Kamu harus mengajarkannya kepada anak-anakmu dengan membicarakannya, apabila engkau duduk di rumahmu dan bila engkau sedang dalam perjalanan, apabila engkau berbaring dan bila engkau bangun. Orang Tua berperan dan bertanggung jawab membicarakan firman Tuhan kepada anakanaknya setiap saat dan menuntun anak remaja memiliki persekutuan dengan Tuhan; 2) Orang Tua menjadi pendidik, sebagai pendidik dalam keluarga menyediakan waktu dan tempat serta memberikan tanggung jawab dengan memercayakan tugas-tugas di dalam keluarga, memantau kegiatan anak di luar sekolah dan menciptakan lingkungan rumah yang kondusif dan mendukung mengembangkan kreativitas anak mereka; 3) Disiplin, Amsal 3:11-12: 19:15,22:15, kitab ini menjelaskan orang tua agar mengajarkan disiplin pada anaknya. Beberapa langkah yang dapat dilakukan dalam mendisiplinkan remaja ${ }^{12}$ yaitu aturan dalam beraktifitas dengan gadget dan mengawasi remaja saat menggunakan gadget; 4) Mengajar melalui keteladanan, orang tua menjadi model dan teladan dalam keluarga harus diterapkan sebagaimana yang dapat kita baca dalam 1 Timotius 4:12 dan 2 Timotius 1:5, di mana Timotius yang masih muda hidup dalam iman karena faktor keteladanan dari neneknya Lois dan ibunya Eunike, dan sekaligus menjadi teladan ${ }^{13}$; 5) Keluarga menjadi Cyber Smart, artinya keluarga yang sanggup mengambil berbagai keuntungan atau manfaat dari kemajuan teknologi dan mengantisipasi atau meminimalkan dampak negatif yang terdapat dalam gadget. Orangtua harus aktif mendampingi dan membimbing anaknya memilih setiap informasi yang tersedia dalam gadget. ${ }^{14}$

\section{KESIMPULAN}

Dari hasil penelitian ini dan pembahasan yang telah dilakukan oleh peneliti, dapat disimpulkan bahwa peranan orang tua kepada anak remaja harus dilaksanakan dan dikerjakan melalui: 1) orang tua mengetahui dan memahami rating game

11 Ibid.

12 Yushak Soesilo, "Penggunaan Rotan Dalam Pendisiplinan Anak Menurut Kitab Amsal 23:1314," DUNAMIS (Jurnal Teologi dan Pendidikan Kristiani) 1, no. 1 (2016): 1-14, www.sttintheos.ac.id/e-journal/index.php/dunamis.

13 Desti Samarenna and Harls Evan R Siahaan, "Memahami Dan Menerapkan Prinsip Kepemimpinan Orang Muda Menurut 1 Timotius 4: 12 Bagi Mahasiswa Teologi," BIA': Jurnal Teologi dan Pendidikan Kristen Kontekstual 2, no. 1 (2019): 1-13.

${ }^{14}$ Elsyana Nelce Wadi and Elisabet Selfina, "Peran Orang Tua Sebagai Keluarga Cyber Smart Dalam Mengajarkan Pendidikan Kristen Pada Remaja GKII Ebenhaezer Sentani Jayapura Papua," Jurnal Jaffray 14, no. 1 (March 2016): 77-92. 
yang digunakan oleh anaknya, rating yang dimaksud disini adalah jenis game yang dimainkan anak; 2) Hindari pemasangan perangkat elektronik di dalam ruangan kamar anak; 3) Menciptakan aturan yang disetujui dengan anak, dengan cara memperlakukan pembatasan waktu dalam menggunakan gadget; 4) Orangtua aktif mengawasi dan memperhatikan media yang sedang dikonsumsi oleh anak, seperti game dan film; 5) Mengkomunikasikan dan mendiskusikan pada anak mengenai apa saja yang mereka dapat dari game atau acara yang mereka tonton; 6) Orang Tua mengontrol play store yang di gadget, dengan cara selektif memilih fitur games yang tidak menimbulkan hal-hal negatif pada karakter anak; 7) Pola komunikasi yang ada dalam keluarga sangat menentukan bagaimana orangtua dapat tetap menjaga anaknya terhindar dari dampak negatif penggunaan gadget; 8) Orang tua harus memiliki kedekatan hubungan yang baik dengan anak sehingga pola komunikasi dapat berjalan dengan baik. Kedekatan hubungan ini harus dibangun bahkan harus dibangun sejak anak masih dalam kandungan, saat itu juga pola komunikasi perlahan mulai dibangun. Hal lain yang harus dilakukan oleh keluarga Kristen adalah mengajarkan firman Tuhan terus-menerus kepada anak dan membimbing anak senantiasa membangun persekutuan dengan Tuhan, Orang Tua menjadi pendidik, sebagai pendidik dalam keluarga menyediakan waktu dan tempat serta memberikan tanggung jawab dengan mempercayakan tugas-tugas di dalam keluarga, mengajarkan disiplin khususnya dalam menggunakan gadget dengan cara memberikan batasanbatasan waktu saat digunakan anaknya, serta mendidik dengan keteladanan dari orang tua dalam kehidupan sehari-hari.

\section{REFERENSI}

Anggraini, Eka. Mengatasi Kecanduan Gadget Pada Anak. Serayu Publishing, 2019. Chusna, Puji Asmaul. "Pengaruh Media Gadget Pada Perkembangan Karakter Anak." Dinamika Penelitian: Media Komunikasi Sosial Keagamaan 17, no. 2 (2017): 315-330.

Iswidharmanjaya, Derry. Bila Si Kecil Bermain Gadget. Desember 2014, 2014.

Nababan, Andrianus. "Pola Asuh Demokratis Orangtua Kristen Dalam Pembentukan Karakter Remaja." Jurnal Dinamika Pendidikan 13, no. 2 (2020): 127-134.

Pangastuti, Ratna. "Fenomena Kecanduan Gadget Pada Usia Dini." Indonesia Jurnal Of Islamic Early Childhood Educatiuon Vol.2, No. (2017): 166.

Samarenna, Desti, and Harls Evan R Siahaan. "Memahami Dan Menerapkan Prinsip Kepemimpinan Orang Muda Menurut 1 Timotius 4: 12 Bagi Mahasiswa Teologi." BIA': Jurnal Teologi dan Pendidikan Kristen Kontekstual 2, no. 1 (2019): 1-13.

Sari, Intan Permata, Rama W Kusuma Wardhani, and Ahmad Syaiful Amal. "Peran Orang Tua Mencegah Dampak Negatif Gadget Melalui Pendekatakan Komunikasi Dan Psikologi * Corresponding Author Pendahuluan Gadget Diartikan Sebagai Suatu Alat Yang Digunakan Untuk Mengakses Atau Menjalankan Suatu Program Tertentu Yang Menarik Dan Ber” 2, no. 2 (2020): 267-289.

Satira, Rahma Lillahi. "Survai: Orang Tua Dan Anak Habiskan Waktu Sama Banyaknya Bermain Gadget." DetikHealth. 
Sirait, Ronald. Digital Karakter Presfektif Agama Dan Pendidikan. Yayuk Umay. CV. Multimedia Edukasi, 2020.

Soesilo, Yushak. "Penggunaan Rotan Dalam Pendisiplinan Anak Menurut Kitab Amsal 23:13-14." DUNAMIS (Jurnal Teologi dan Pendidikan Kristiani ) 1, no. 1 (2016): 1-14. www.sttintheos.ac.id/e-journal/index.php/dunamis.

Subagijo, Azimah. Diet Dan Detoxs Gadget. PT Mizan Publika, 2020.

Wadi, Elsyana Nelce, and Elisabet Selfina. "Peran Orang Tua Sebagai Keluarga Cyber Smart Dalam Mengajarkan Pendidikan Kristen Pada Remaja GKII Ebenhaezer Sentani Jayapura Papua." Jurnal Jaffray 14, no. 1 (March 2016): 77-92. 